UDC $\quad 669.14 .018 .252 .3$

解

説

\title{
高速度工具鋼に関する最近の動向*
}

\section{Recent Trends of High Steel Tool Steel}

清 永 欣 吾**

\section{Kingo KIYONAGA}

\section{1.はじめに}

高速度工具鋼はW，Moを多量に含む二次硬化性を 有する耐熱, 耐摩耗工具鋼で切削工具, 冷間圧造工具そ の他耐熱性，耐摩耗性が要求される種々の工具あるいは 構造部品に広く使用されている. わが国の年間生産量は 約 2 万 t で，での約 6 割が輸出されている. Fig. 1 に昭 和 40 年を 100 上した場合の各種工具鋼の生産指数の推 移を示すが1)，特殊鋼に比し工具鋼の生産の伸びが低い のは，工具材料の高級化による工具寿命の増加および使 用技術の進歩による工具使用量の相対的隇少によるもの と考えられる。高速度工具銅は工具鋼の中では生産指数 の伸びが高いが，これは輸出の增大上冷間加工工具への 応用の拡大によるものであろう. 高速度工具鋼と競合的

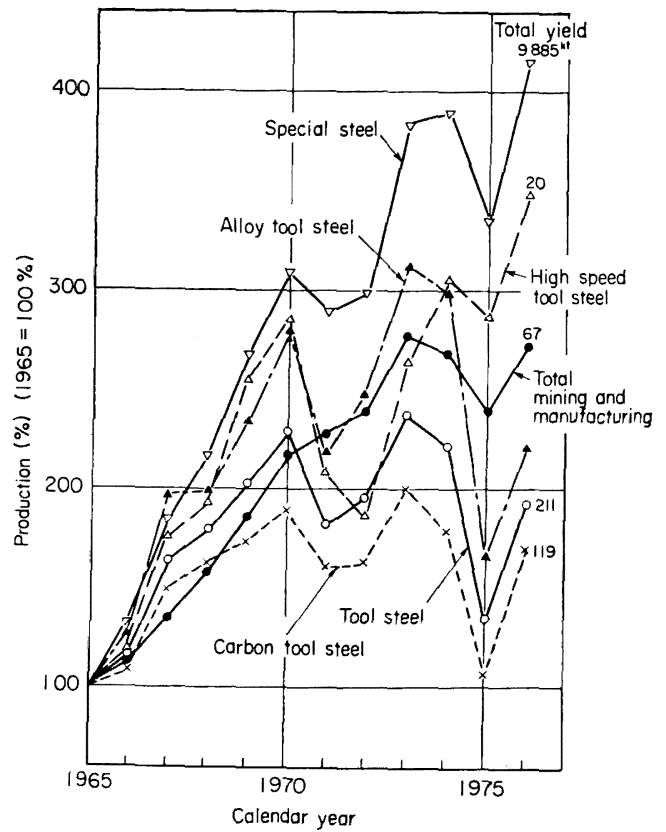

Fig. 1. Production of various tool steels in Japan.
立場にある超硬合金の工具生産額を比較すると Fig. 2 のごとく，おおむね相拮抗しているが2)，昭和 45 年以 降超硬工具の生産がやや優位に転じている.これはミり ング工具の分野における超硬工具の進出が激しいことに よるものである、しかしながら，高速度工具鋼のすぐれ た強勒性，耐熱性，耐摩耗性および生産性のために，高 速度工具鋼は今後もなお活力を維持し，主要な工具材料 として発展して行くものと思われる.

本稿では高速度工具鋼の最近の動向について，とくに 1970 年以降の動きを中心に紹介し, 読者の御参考に供し たい.

\section{2. 鋼 種の動 向}

\section{$2 \cdot 1$ 歴史的推移}

高速度工具鋼の起源は明確には定め難い.1898年アメ リカ, ベスレへム社の TAYLOR および WHITE は 1861 年 MUSHET が発表した高炭素タングステン自硬性鋼に 高温焼入処理を施すことにより，著しく赤熱硬さを高 め，切削時の工具寿命を增大することを発見したが，そ 九以降, 改良が急速に進み，早く\&1906 年にはSKH2 とほとんど同じ化学組成の高速度工具鋼に到達してい る. その意味で 1898 年を高速度工具鋼の起源とみるこ とができる.

1930 年まではW 系高速度工具鋼の完成と充実期であ

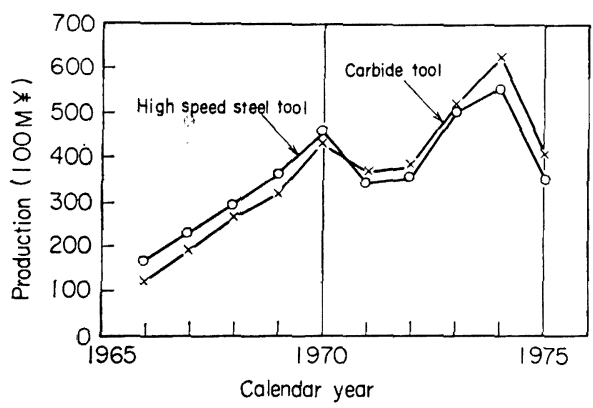

Fig. 2. Comparison of production of carbide and high speed steel tools in Japan.

* 昭和 53 年 1 月 9 日受付 (Received Jan. 9, 1978)

** 日立金属(怢)安来工場 工博 (Yasugi Factory Hitachi Metals Ltd., Yasugi-cho Yasugi 692) 
る. 1930 年代に入り,アメリカでMoの大鉱脈が発見さ れ，アメリカを中心にMo 系高速度工具鋼の研究が活発 に行なわれ，1932 年には Mo-Max (AISI. M1) が Emmons によって発表され，1937 年には HoudREMONT らによって今日の SKH9 の基礎となる W-Mo 高速度 工具鋼が発表された。第 2 次浀界大戦はWの払底のため に，Wを節約した代用鋼，Mo 系高速度工具鋼の開発が 促進されたが, 戦後, アメリカが工業技術の中心となるに 及えで，W 系からMo 系高速度工具鋼への枟換が世界 の潮流となつた。1950年代中葉には今日の主要な高速度 工具鋼はほとえど AISI に制定され，アメリカに打け る Mo 系の生産は $90 \%$ 究淩駕するに到つた。

今日の高速度工具鋼は 1950 年代に一忘完成したとみ ることができる. 高速度工具鋼の析出硬化機構き熱処理
による諸性質の変化が明確にされたのも当時である。

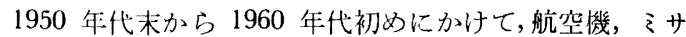
イル部品に用いられる耐熱合金，高強力鋼などの難削材 切削工具として，高硬度で靶性および耐熱性の高い高速 度工貝鋼の開発が必要となつた，その絬果，元来靶性の 高い Mo 系高速度工具鋼をべースに，ての Cおよび Co 量を增加させた新材料が繶々と発表された。高炭素M2, AISI, M40 シリーズがそれである.

1960年代のもう一つの流れは塑性加工用工具への高速 度工具鋼の応用であり，またそれに聥した新鋼種の開発 である.冷間鉎造用パンチでは折損事故が多く発生し， 鞂性を一層高めるための熱処理（アンダーハードニング 処理，ベイナイト処理）が研究され，新材質として低炭 素高速度工具銅や，高速度工具鋼のマトリックス・スチー

Table 1. Chemical composition and main usage of present high speed tool steels.

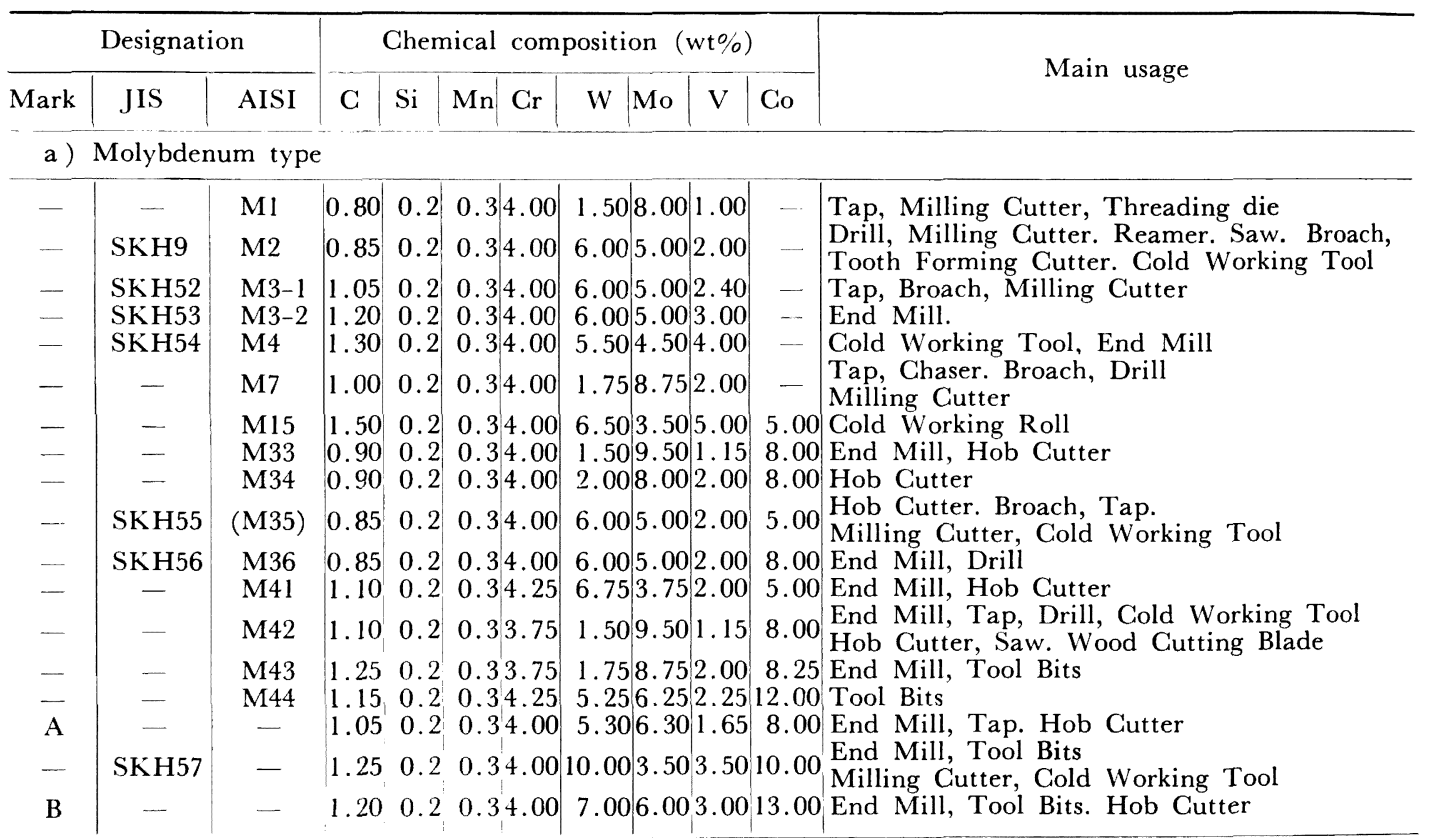

b) Tungsten type

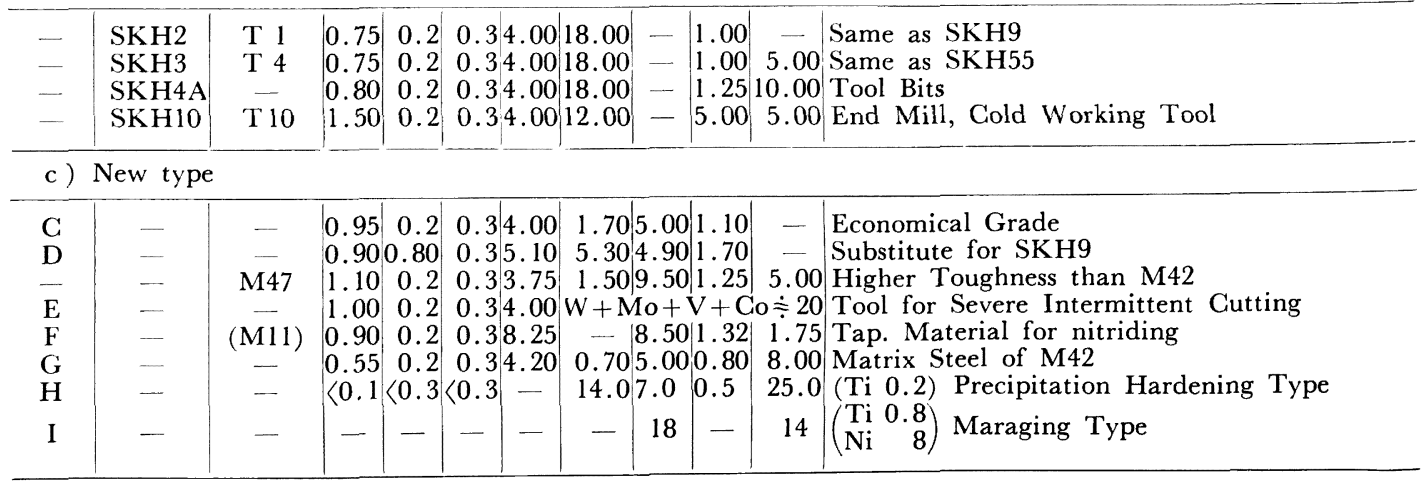


ルあるいはその修正鋼などが開発された。

\section{2 現在の高速度工具鋼の種類とその動向}

Table 1 に現在実肚されている高速度工具鋼の種類と 主要な化学成分および用途を示す．既述のごとくW系高 速度工具鋼は高速度工具鋼の主流から完全に没落し，現 在では一部の特殊川途(バイト材，木工物，耐摩耗材） で命脈を保つているに過きない。

Mo 采の主流は SKH9 と SKH55 である. 前者は各 種切削工具，冷間金型の標準材料として幅広く使用され 後者はその高級材としてのほか, ホブカッターなど蔽り 工具類に主に使用されている. SKH57 は現用 JIS 高速 度工具鋼のうちでは，もつとも切削耐久性のすぐれたも のであり, 完成バイト材, 難削材切削用カッター, エン ドミル材として使用されている.

しかし，これらの材料はいずれもW約 $6 \%$ 以上点む いわゆるW-Mo 系高速度工具鋼であり，近年のW枿格 の高騰により高 Mo 系へ移行する可能性が大きい，AI SI, M7 はその意味で注目され, SKH9 に比べ耐熱性, 耐摩耗性がすぐれ，かつ同程度の䩖性をもつため，次第 に需要を増加しつつある. 現在, ハイスタップのほとん どはM7であり，そのほかフライスカッター，チェザ 一,ドリル，ブローチなごで SKH9 に代る材質として 注目されている.

AISI·M40 系3)も着実に它の用途を拡げつつある・M 42 が主流で，そのほか M41，M43，記号Ａ銅4)などが エンドミル，ホブ，高級タップ，木工及物，鋸及，金型 などに用いられている.

これらのほか，種々の冷間あるいは温間加工用金型材 が高速度工具銅の範ちゆうの中で開発され実用されてい るが，ほとんど化学成分が公表されていない。

Table 1 に最近発表された新しい高速度工具銅を併戌 した。これらは高速度工其鋼開発の方向を示唆するもの として興味深い，そこには合金原料の高膫に対処した低 合金高速度工具鋼 $\left(\mathrm{C}^{5}\right)$ 抢よび $\mathrm{D}^{6}$ 鋼), M40 采の文省

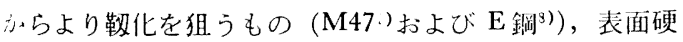
化法を利用した新しい開発材料 $\left(\mathrm{F}_{\text {鋼9) }}\right)^{2}$, 耐熱性と靶性 を兼備する冷間塑性加工片高速度工具鋼 $\left(G_{\text {銅 }}{ }^{10)}\right)$, 析出 硬化型の新しいタイプ ( H $^{11}$ 抢よびI 銅 $\left.{ }^{12)}\right)$ など, 高速 度工具鋼の将来動向に刘与る萠芽があるように思われ る.

以上は溶製材を対象とした新材料で，そのほか粉末治 金法を前提とした新しい材料開発も行なわれている.

\section{3. 高速度工具鋼の一次炭化物}

高速度工具鋼の硬化機楆に関連して, 焼もどし第 1 過 程から第 5 過程に到る炭化物反応は主として 1950 年代 に研究され，1960年代は高速度工具鋼の機械的性質に関 する研究および一次炭化物分布改善に関する製造研究が 数多く発表された. 1970 年代になり, 高 Mo 系高速度
工具鋼の一次炭化物の特異な晶出形態から, 一次炭化物 の種類，形態あるいは㠜困変態に及ぼす合金元素の影響 についての研究が各所で行なわれた。

\section{1 一次炭化物分布, 粒度の影響}

一次炭化物状態と高速度工貝鋼の各種性質との関係に ついては定量的データは極めてそしい，密集した恢化物 または厚い縞状炭化物組織をもつ工具は切削㭙に突然及 かけを生じや-すく好ましくないが13)，連続した一次炭化 物網はたとえそれが薄くても鞁性には有宫で，むしろ厚 くても不連絟の方が靶性が高い14). 清永 ${ }^{15)}$ によれば高速 度工具銅の抗折力, 衝揧值, 振り及び引張特性, 疲れ強 さなどの機械的性質は[炭化物偏析部のマトリックス面 積染 /最大炭化物長さ $]^{1 / 2}$ の值と相関し，この值の大き いほど各種機械的性質が改善されるとした。 QUEENCY ${ }^{16)}$ は鈰塊の予備拡政加熱 $\left(780^{\circ} \mathrm{C}\right)$ 時間と鍛造比が AISI, M1 の破壊靶性值に及ぼナ影響を研究し, 低い加工率の 場合, 長時間予借昖敖処理が破壊靶性值を改善与ること を示した。

炭化物サイズに関しては, 小さい方が熱処理硬さが高 く, 压縮, 引張強さ, 靶性, 被研削性が-すぐれるが17), 耐摩耗性は低下し, 連続比㴥時の工具寿命を一般に低下 させる.しかし，䩖性要因の入る高硬度ワークの切削や 断続切削では逆に工具寿命を増大させる傾向がある ${ }^{18)}$.

\section{2 凝固機構}

Mo 系高速度工具鎆の凝侀機構については最近多くの 研究が発表され，合金元素の影響も明らかになりつつあ る. C の増加は $\delta$ 共析を減少し, MC炭化物を粗大化与 る19)20). V, Mo は $\delta$ 相域を搪大し, MC炭化物を粗大 化与る19). W を Mo に置换すると MC の $\mathrm{M}_{6} \mathrm{G}$ 炭化 物に対导る敖合が増加することなどが知られている21).

\section{$3.3 \mathbf{M}_{2} \mathbf{C}$ 一次炭化物}

高 Mo 系高速度工具鋼の鍛延材の組織中に $\mathrm{SKH} 2$ や SKH9 ではほとんどみられないロッド状の一次炭化物が 譍々钼察されるが，これが $\mathrm{M}_{2} \mathrm{C}$ 炭化物であることが $\mathrm{STEVEN}^{22)}$ らよって明らかよなり，近年この $\mathrm{M}_{2} \mathrm{C}$ の 生成条件や熱処理挙動についての研究が活発となつた。

$\mathrm{M}_{2} \mathrm{C}$ は $\mathrm{Mo}_{2} \mathrm{C}$ に類似した格子常数をもち， $\mathrm{Si} ， \mathrm{~N}$ は $\mathrm{M}_{6} \mathrm{C}$ の形成を促し， $\mathrm{M}_{2} \mathrm{C}$ を不安定化するのに対(22)23), $\mathrm{C}$ は $\mathrm{M}_{2} \mathrm{C}$ を安定化与る24). $\mathrm{M}_{2} \mathrm{C}$ は元来不安定な炭化 物で高温加熱により崩壤して $\mathrm{M}_{6} \mathrm{C}$ と $\mathrm{MC}$ に変態する25)。 この変態は約 $700^{\circ} \mathrm{C}$ で開始し, $\mathrm{Si}$ 量の多いほど加速さ れる26. SKH9 および M7 の初晶および共晶炭化物の 種類に及ぼす $\mathrm{C} ， \mathrm{~N}$ および邻速度の影蚃に関しては FREDERIKSSON の研究27) があり, 低冷却速度の壇合, $\mathrm{M}_{2} \mathrm{C}$ （高 $\mathrm{C}$ 量の場合）または $\mathrm{M}_{6} \mathrm{C}$ （低 $\mathrm{C}$ 量の場合）が 最初の炭化物として晶出するが, 高冷却速度の場合は $\mathrm{C}$ 量によらず MC が初晶炭化物として晶出し， N の高い ほどその晶出温度が上昇すること, 冷却速度の高いほど 共晶炭化物量が減少することなど興味ある結果を発表し 
ている、なお， $\mathrm{M}_{2} \mathrm{C}$ の晶出上機械的性質の関係につい ては十分なデータがない.

\section{4. 高速度工具鋼の製造法の動向}

高速度工具鋼の一次炭化物ネットワークを微細化卞る ために多くの方法が恰副されてきた。接種法，鈜型予熱 あるいは発熱性鋳型法, 振動または拍拌法, 銤型急冷法, 高压鋳造法, Durville 江, ESR 江, エレクトロンビー 么溶解法，粉来汸金法などがをれである。

しかし，高速度工具鋼の共晶組織を確実に微細化する 方法は凝固時の泠却速度を大にすることである。BRA一 NDIS ら 28) によれば鋳込温度の影響はほとんどないが冷 却速度の刘数已初晶サイズ, 炭化物サイズ, 炭化物偏析 度はほぼ直線関倸があることを示し，石川，須藤ら ${ }^{29}$ は 柱状晶と粒状晶の生成条件を倹副し，同一泠却浬度の場 合, 柱状晶領域では粒状晶域と比較し, 粗大炭化物量が 減少することを示している.

E S R 法は鋼中の非金属介在物を除去するのに效果が あるほか，鋳造組織が均一で偏析が減少するなどの効果 があるため，高速度工具鋼の製造法上しても注目されて いる、 KIRK ${ }^{30}$ によれば ESR の効果は $100 \phi$ 以上の大 径材で有効で，FIEDLER ${ }^{31)}$ によれば鍛錬成形比 2 まで製 品乞して使用可能という.炭化物サイズの微細化に対し ては一致した見解はない，ES R 䤱では横方向の機械的 性質, 疲れ強さが改善されることが AISI, D2, A2 で 知られているが322高速度工具鋼については詳しいデータ はないＥＳＲに接種法を併用して炭化物偏析をさらに

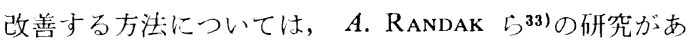

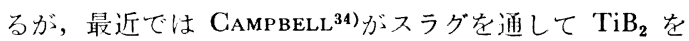
添加し，初晶の微細化に成功している。

粉末治金法に上る高速度工具鋼の製造は，工業的には 1970年スエーデン, STORA 社, 米国 CRUCIBLE 社 がその量産化を発表したのが最初である。これらの製造 法に関してはすでに公表文献 ${ }^{35)} か ゙$ 多いので省略する。粉 末高速度工具鋼の特性は一次炭化物が㥛好て均一に分散 し，かつ微紐であるという特色によつて決定づけられ る. その特性を列挙与る上次の通りである.

（1）鞁性が堌大し，耐チッピング性が良好となる.

(2) 被䂧㴥性がいちじるしく改善される.

（3）熱処理変形が減少し，上くに材質に起因する不 均一変形が少なくなる.

（4）熱間加工が容易となり，従来のものより高合金 のものまで製造できる.

（5）工具寿命のバラッキが少なくなる.

耐摩耗性については既述のごとく炭化物粒度に対与る 低存性が強く, 微細な場合はかえつて低下寸る。年れ故 粉末高速度工具鋼の䛧值は強い断続切削のごとく邓先に 从けやチッピングを尘じやすい工思，マイクロチッピン グにより摩耗が進行する工具, 研削工数の大きい工具,
するどい刃先強度を必要とする仕上切り工具などに適す る上考えられる。

粉末治金技術を利用した新材料開発の方向としては, $\mathrm{VG} ， \mathrm{TiC}$ なよ゙の硬質粒子を分散させて耐摩耗性を増大 するもの ${ }^{36) 37)}$, N含有量を富化させるもの ${ }^{38)}$ な゙゙が発表 されているほか，粉末技術を忍用した焼結工具，複合工 具の研究が実施されている.

粉末高速度工具鋼でどこまで高合金のものが製造でき るかは興味深いが, prealloy 膹霧粉を用いる場合, 安藤 ら39によよれば $\mathrm{C}>5 \% ， \mathrm{~V}>25 \%$ になると溶融状態で粗 大な VC を生じ，水アトマイズ粉でも粗大 VC の生成 を阻止できないとしており，この付近が限度と考元られ る. LuPI $\left.{ }^{40}\right)$ は通常の高速度工具鋼より $20 \%$ 以上合金量 が高いと著しく熱間，冷間の加工性が劣化するといって いる.

\section{5. 高速度工具鋼切削工具の損耗現象}

近年，工具損耗現像を金属組織的に解明し，工具の使 用技術あるいは新材料の阙発に空用しようとする傾向が 盛んになつているししかしながら，比削工具の損耗は非 常に多くの要因によって支配されるため, 損耗のメカ二 ズムについても諸説が提起されまだ固つていない。

\section{$5 \cdot 1$ クレータ摩耗}

中〜高速比削時のクレータ摩耗の速度は Cook ${ }^{41}$ によ れば温度の関数であり，切削中熱的に活性化した工具表 面から原子が被加工材へジャンプナる形で摩耗が進行寸 ることをクレータ摩耗の活性化エネルギー值より推論し ている. BROWNSWORDら (2) は高速切削の場合焼き付きが 起こり, 工具表面が塑性流動与る形で摩耗が進行与る上 し工具の高温における flow stressがクレータ摩耗の支配 因子であるとする。市た低速切削時の穈耗は BUE（愫 成邓先）の脱落によるアブレーシブ摩耗上溶着物が制蜼 する際すくい面から工具材をピックアップする湖進的ア ドヒーシブ摩耗が主体であるとしている.

OPITZ 技よび KöNIG ${ }^{43}$ (は BUE の挙動が工具摩耗に 顕著な影響を与元, 安定な BUE 生成域ではクレータ摩 耗は少なく, 切削速度が増大し, BUE が消失すると, BUE の保蓄作用がなくなり，また刃先温度の上昇によ る工具強度の低下によってクレータ摩耗は急增すると述 べている.

WRIGHT および TRENT44) は数種のワークを切削した 場合の刃先金属組織を詳細に镜察し，いくつかの縻耗バ ターンを提出している.すなわち，(1) 工具すくい面の 非常にうすい部分に生ずる整断塑性流動的摩耗，(2)压 縮応力による刃先のマクロ的塑性変形, (3) アブレーシ ブ摩稚，(4) 拡散摩耗，(5) Attrition 摩耗がそれであ る. このうち, 拡散摩耗は溶着物と工具界面の間の拡散 による工具表面強度の低下に起因する摩耗で，その界面 に生ずる White Layer の存在が拡散摩耗を傍証するも 
の上して最近注目され，研究されている.

Attrition 魔耗は刚先先端に現れるマイクロチッピン グ的摩耗で, 大草, 高橋ら45)のいう斜め形チッピングも 同種のもの乞考えられる。この摩耗形態は高速切削では 起こらない。いづれにせよ，クレータ摩耗は高速切削の 場合に問題であり，メカニズムは如何であれ切削熱が主 要な要因であることは一致している.

\section{2 フランク摩耗}

比較的低速切削ではフランク摩耗が工具寿分の支配因 子乞なる。これは B UE の生成状況によって著しく影 響をうける. 大草，高橋，西沢ら46) はワークの種堛に より突起形と扁平形の B UE が生じ, 突起形の場合, 切削条件により摩耗形態が㥛めて变化与ると報告してい る.

B UEに関連して溶着や焼き付きに関する研究も進み つつある、KABALON47) は高速度工具鋼の方が超硬より 切屑上の溶着力が強く，ステンレスは構造用鋼より工具 に対する溶着力の大きいことを示している．大沢ら年は 高速度工具鋼の耐焼き付き性を研究し，Mo-Co 系高速 度工具鍋（SKH55，56）がW系やSKH9 より耐焼き付 き性が大きいことを示した。

DOYLE49によれば S45C の旋削において，SKH9 の 焼もと゚し不十分な工具は大きなフランク摩耗を示し，ク レータ摩耗は少なかつたが，焼もどしの十分な工具は逆 にクレータ摩耗が大きくフランク摩耗が大であったとい う.この場合，BUEの形態も異なつていたことを報告 しているが，佐久間50)によれば熱伝䆃率の小さい工具任 ど刃先温度の上昇が激しく, B U E の消減が早い.

\section{3 チッピング}

一回の切削ないしは衝牶で生ずる久損を除けば，チッ ピングは低サイクル疲れ破壊の一種上考えることができ る. 疲れの外部要因として, 熱忍力および挋による機 械応力があり，これらに刘し，工具形状，切削条件，表 面粗度, 冷却条件, B U E の状態, 工具材質などが閔係 する.

切削時の工具刃先に生ずる応力分僬を有限要素法を朋 いて解析する研究 51)，フライス切削における工具欠損を 熱衝揧および熱亀裂の立場から研究したもの 52 など理論 面から追求与る方向の研究が種々発表されているが，な だ現実とのギャップが大きい，それは工具の熱的あるい は機械的疲れ強さに関する研究が不十分であり, かつ工 の破壊がかなり確率的特性のものであるからである. 具井ら ${ }^{53)}$ は工具の破壊確率がワイブル分布にしたがうも のと仮定して，チッピング現象を解析与る試みを行なつ ている.

NEUMEYER ら ${ }^{54)}$ はオーステナイト結晶粒度の微細なほ ど断続切削時の摩耗単位が微小であり，いわゆるチッピ ング摩耗を小にすることを示しているが， BHAUACHARYYA ら5)
合，同様の結果を得ている.

繰返し打紧による高速度工具鋼の耐チッピング性につ いては清永ら56の研究があるが，彼らによれば刃先舟の 小なるときは土具硬さが，㹝先话の大なるときは工具材 種の疲れ破壊特性がチッピングに大きな影響を与元る. 高速度了.其鋼の繰返打慗による耐チッピング性は， C お よび Co 量の少ないほど一般にすぐれている.チッピン グに関しては，てれが察際上㥛めて重要であるにもかか わらず現象的にも, 理論的にも, まだかなりの研究余地 が残されている。

\section{6. 高速度工具鋼の機械的性質}

高強度材の䩲性評仙に IRWIN がクラックの近傍の応 力学弾性諭的に解析し発展させた破垻䩲性試験法があ る. JoHNSON ${ }^{57)}$ は M2 およびM7 の破壊鞉性值 $\mathrm{K}_{1} \mathrm{G}$ と 熱処理条件の関係を求め，HRC 50 以下では烍入温度に 関係なく $\mathrm{K}_{1} \mathrm{C}$ と硬さは直線的関係を示すが， HRC 60 以上では焼入温度の低い方が $\mathrm{K}_{1} \mathrm{C}$ は高いことを示して いる. 一方, 高跎ら58) は SKH9 の $\mathrm{K}_{1} \mathrm{C}$ は Hv500〜 870 の笵囲で焼入温度にかかわらず硬さの高い忹ご直線 的に低下亦る結果索得ている. BERRY ら59) は2, M 3-2 について焼入, 焼もどし温度と $\mathrm{K}_{1} \mathrm{C}$ と断続切削時 のチッピング発生サイクルの関係を求好ているが，硬さ と $\mathrm{K}_{1} \mathrm{C}$ の直線性は $\mathrm{Hv} 800$ 以上で認られるものの, そ れ以下ではあまりよくない。

高速度工具鋼の疲れ強さに関与る結尘はあまり公表さ れていない. 新持, 浦野60)によれば SKH9 の $10^{7}$ 疲れ 強さは焼入温度の高い力が大きく, $10^{5}$ 疲れ強さは中程 度の焼入温度 $\left(1200^{\circ} \mathrm{C}\right)$ で大で, それより高くても，低 くても疲れ強さは低下子る。烧もどしに関しては $575^{\circ}$ C 付近が種々の煳入およびサイクル条件でおおむ枚最良 の結果を示す. TKEMALADZE ${ }^{61)}$ は種々の高速度工具鋼の 疲れ強さを求め, W, Co 量の增加, 㷪入時の過熱が疲 れ強さを減じ，疲れ強さは抗折力のほぼ17〜20\%であ ると報告している.

\section{7. 高速度工具鋼の冶金学的性質}

\section{$7 \cdot 1$ 化学成分の影響}

Mo 高速度工具鈰に生ずる $\mathrm{M}_{2} \mathrm{C}$ 炭化物の分解に Si, Nの添加が有効であることが知られているが，これに関 連し，種々の性質に及ぼす $\mathrm{Si} ， \mathrm{~N}$ の影響が研究されて いる.

$\mathrm{Si}$ ：㷪もどし硬さを高くし，低温筧入でも硬さを出や すくするが，0.4\% 以上では高温の烍もどし抵抗を減ず る(2)靶性については, SCHLATTER ${ }^{63)} や J_{\text {JOHNSON }}^{64)}$ は Si 添加により変らないか，若干改善するとしているのに刘 し，HENRY65) はむしろ低下させるとしている. HEnRY によれば， $\mathrm{M}_{2} \mathrm{G}$ ロッド状炭化物の存在は靶性を低下し ないという。 
$\mathrm{N}$ : Kutuev66), KREMNeV ら ${ }^{67)}$ はN $\mathrm{V}$ と結合し, V(CN)のサイズを大にすること，䩖性も改善すると述 べているが，河合ら ${ }^{38}$ ) は鞄性は低下寸るが，二次硬化性 耐摩耗性を增大寸ると報告している。

$\mathrm{C} ： \mathrm{C}$ 添加により燒もよ゙し抵抗が著しく增大する機满 は十分には分つていない. CHODOROWSK ${ }^{68}$ は $\mathrm{C}$ 增加に より焼入時に固溶する $\mathrm{W}, \mathrm{Cr}$ は減少するが，残留オ一 ステナイトの分解，マルテンサイトからの炭化物の析出 および成長過程が極めて遅れることを示している。 また BERTHON によれば69) SKH9 のC増加により $\mathrm{M}_{2} \mathrm{C}$ が形 成し，それが高い焼入温度で固溶して残留オーステナイ トを多くするという.

Co : ZyKova ${ }^{70}$ によれば Co は烍入侍に炭化物の固溶 を增加し，橴もどし時，遷移炭化物の析出温度を低下し かつ析出炭化物を極めて微細に分散させる.

\section{$7 \cdot 2$ 熱処理の影響}

高速度工具鋼の恒温焼鈍法は熱経済の点で有利である が，これは二次炭化物の析出速度が速く，変態時の残留 応力が急速に除去されるからである．恒温焼鈍材は焼入 によりオーステナイト結晶粒をやや粗くするが，バラッ キを少なくし，抗折力は他の烓鈍法より優るという(1). GELLER $^{22}$ は完全烓鈍の温度が高すぎると呰入性を減じ， 二次硬化性を減少させるとして $860^{\circ} \mathrm{C}$ 以上の焼鈍ある いは $800^{\circ} \mathrm{C}$ 以上で $10 \sim 18 \mathrm{~h}$ 以上の保持を禁止してい る. HABERLING ${ }^{73}$ によれば，銅塊の拡散焼鈍は偏析除去 に有効であるが，最適条件があるという，高速度工具鋼 の焼入の際の溶融開始温度と化学成分の関係については STEVEN $^{74)}$ の式がある.

$$
\begin{aligned}
& T\left({ }^{\circ} \mathrm{F}\right)=2310-200(\% \mathrm{C})+40(\% \mathrm{~V}) \\
& \quad+8(\% \mathrm{~W})+5(\mathrm{Mo})
\end{aligned}
$$

しかし，この温度は加熱保持時間によって変化する.

KULMBURG ${ }^{75)}$ は種々の高速度工具鋼についてこの関係を 求好ている.

高速度工具鋼の真空焼入は無公害, 熱処理肌が美麗, 熱処理変形が少ない，研削が不要あるいは刃付䂤削のみ でよい，作業環境がよく自動化ができるなどの利点によ り, 小物工具, 塑性加工用工具を中心に今年増加しつつ あるが, 焼入性および表面異常層の問題がある。 LECKIEEWING ${ }^{76)}$ は高速度工具鋼の焼入冷却速度が逯いと約 $1000^{\circ} \mathrm{C}$ 付近で $\mathrm{Mo}_{2} \mathrm{C}, \mathrm{MC}$ 炭化物が結晶粒界に析出 し，二次硬化を減少させることを明らかにした。浅井ら 77) は $\mathrm{W}$ 系の方が $\mathrm{Mo}$ 系高速度工具鋼より上記の意味に おける焼入性の減少が少なく, C, Co は焼入性を增大さ せると報告している.

真空烧入時に生ずる表面異常層はステンレス・バスケ ットを用いる際の $\mathrm{Cr}$ 蒸着, 真空油焼入の場合は表面浸 炭によるもので69), ともに表面に安定な残留オーステナ イトを生(゙78)，耐摩耗性が上昇与るといわれる79)。

高速度工具鋼の焼入時に生ずる混粒現象についても種
々の報告がある. POPANDOPULO ${ }^{90)}$ は炭化物椟が不斉で, 不均一な固溶体を形成する場合, ADASKIN ${ }^{81)}$ は一次炭化 物分布が不均一な場合, KHAZANOv'2) は熱閒圧延の温度 が高く，加工率の低い場合，それぞれ混粒を発生しやす いとしている. 二回焼入の際に生ずる異常粗粒について は清永 ${ }^{83)}$ ，辻ら ${ }^{84)}$ の研究がある.

高速度工具鋼は適当量の $\mathbf{C}$ と炭化物形成元素を含むた めオースフォーミスグに適するものである. 靶性の向上 効果, 低温烍入でも高い二次硬化性を与えるなどの利点 があり，SKH9 やマトリックス・スチールには有効であ るが Co 含有鋼や粗大な一次炭化物を含む場合は勃果が ない85)。オースフォーミングの実用例は少なく，一部小 径のコールドフォーミング用パンチに適用されているに 過ぎない，高温に打ける加工熱処理は，加工中に炭化物 析出が起るため高速度工具鋼には適さない86)。

\section{3 高速度工具鋼の表面処理}

高速度工具銅の表面処理としては旧くより窒化, 軟窒 化, 洨硫空化, 酸化, 硬質クロムメッキなどが一般に実 施されているが，上記のほか新しい表面処理で注目され ているものに，次の処理がある.

(1) 酸窒化処理 $\left.\left.{ }^{87}\right) 88\right): 600^{\circ} \mathrm{C}$ 以下の適当な温度でア ンモニヤと水蒸気の混合物の雲囲気に曝して酸化と窒化 を同時に行なわさせるもので，工具寿命は無処理のもの に比し，平均 70\% 增大寸るという。

（2）硬質炭化物被稪：WC や $\mathrm{TiC}$ を工具表面に電 着させる放電硬化法 ${ }^{88}$ ) は難削材切削用ホブなどに一部使 用されているが，表面粗さが低下寸る，処理時間が長い， 電着部下部に熱影響による軟化層を生ずるなどの問題が ある. $\mathrm{TiC}$ 被覆法としては $\mathrm{TiCl}_{4}$ と炭化水素の混合ガ ス中で 900〜 $100^{\circ} \mathrm{C}$ に加熱し, 工具表面に $\mathrm{TiC}$ を形成 させる気相ィッキ法, $\mathrm{Ti}$ その他の炭化物形成元素を添 加した溶融塩中に渗清し炭化物層を被覆する拡散被覆処 理, PVD 法（物理的蒸着法）の一種で低温で効率よく 密着性のよい炭化物被覆をつくる A R E 法（活性化反応 蒸着法)などがある.前 2 者は主として耐摩部品, 金型 への応用が多く，ARE 法は切削工具用として注目さ れ, 無処理に比し約 3 倍の寿命があるという ${ }^{89}$.

（3）その他: GoGolev ${ }^{90)}$ は $\mathrm{Mo}_{2} \mathrm{~S}$-樹脂のアンチフ リクション被覆および $\mathrm{NiP}$ 被覆（電気メッキ）を施し たホブの摩耗を研究し, 前者で約 1.8 倍, 後者で的 2.3 倍の寿命を示したという. ドリルに NiP 処理を施した 例では約 3 倍の寿命を得ている.

表面処理に適する高速度工具鋼の開発の面では, タッ プ用高 $\mathrm{Cr}$ 系高速度工具銅 VANCOMO ${ }^{9}$, 酸窒化処理 により寿命を増大する SW3S287)がある. 高速度工具鋼 の浸炭はり連でよく研究されているが91992), 米国の $\mathrm{HA}_{\mathrm{A}}$ $\mathrm{RVEY}^{93)}$ は浸炭に適する新しい材料の発明を行ない, この 中で $\alpha$ 相と $\gamma$ 相形成元素の新しいバランスを与える式を 提出しているのが注目される. 


\section{8. おわりに}

1970年以降の高速度工具䤱に関与る技術的動向を中心 に紹介したが，少ない紙数の中に多量の内容を織り込も うとしたため，平板な記述に終つた．この中で，現在の 高速度工具鋼の開題点とその克服の試みがどのようにさ れつつあるか, 記述の不足を読者の識見で補つて理解し ていただければ幸いである。

\section{交献}

1）鉄鋼統計月報，昭 $40 \sim 51$

2) 通商産業省: 機械統計年籃, 炤 $41 \sim 51$

3) J. T. Berry: High Performance High Hardness High Speed Steels, Climax Mo, Co Conneticut (1970) 57

4) 清永欣吾, 中村秀樹: マシニスト，6(1972), p.3

5 ) ベンクト・ヴォデル：D-950-新しい高性能な低 合金高速度工具鋼，スエーデンテクニカルウィー ク $(2 / 25,1972)$ 東京高輸プリソスホテル

6) DEW: Technische Information Nr. A19(1975) Feb

7) P. R. Borneman: Metal Progr., 97(1970), p. 88

8 ) 清永欣吾: 日立評論, 59 (1977) 6, p. 509

9) Manufacturing Engineering and Maragement, July 1975

10) $M$. E. Bush and $R$. WARD: Metallurgia and Metal Forming, 43 (1976) 10, p. 346

11) V. Ya. Gancho: Stal', 9(1972), p. 842

12) Ю. А.Геллер, Л. С. Кремнев, and В. А. Јинник: Metalloved Term. Obsab. Met., 5 (1976), p. 11

13) F. Rapatz: Die Edelstähle (1962-Springer), p. 803

14) $N . F$. Silantéva and $A$. $A$. Govorov: Izvest Vuz. Chern. Met., 11 (1968) 2, p. 125

15) 清永欣吾: 「鋼の強鞋性」, (Oct. 1971, Climax Mo. Co), p. 207

16) $R$. $A$. Queency and $R$. A. Hefeelfinger: Met. Trans., 8A(1977) Feb., p. 369

17）高島孝弘，福塚淑郎：鉄と铜，63 (1977) 11, p. 418

18）清永欣吾，中村秀樹：鉄と鋼，63 (1977) 11, p. 419

19) $H$. Brandis and $K$. Wiebking: DEW Tech. Ber., 11 (1931) 3, p. 139

20) R. H. Barkalow, $R . W$. Kraft, and $J . I$. Goldstein: Met. Trans., 3(1972) Apr., p. 919

21) E. J. Galda and $R$. W. Kraft: Met. Trans., 5 (1974) Aug., p. 1727

22) $G$. Steven, $J . J$. Hauser, and $T$. A. Neumeyer: Trans. ASM., 62(1969), p. 180

23) E. Haberling and $H$. Kiesheyer: DEW. Tech. Ber., 12 (1972) 3, p. 213

24) $K$. Bungardt, $E$. Haberling, $A$. Rose, and $H$. H. Weigand: DEW Tech. Ber., 12 (1972), p. 111

25) E. Horn: DEW Tech. Ber, 12, Heft 3 (1972), p. 217

26）石川英次郎，須藤興一：鉄と鋼，63(1977) 6, p. 990
27) $H$. Frederiksson and $S$. Brinsing: Scand. J. Met., 5 (1976), p. 268

28) $H$. Brandis and $K$. Wiebring: DEW. Tech. Ber. 11(1971) 3, p. 158

29) 石川英次郎，須藤興一：電気製鋼，48(1977) 1, p. 33

30) F. A. Kirk, H. C. Child, E. M. Lowe, and T. $J$. Wilkins: JISI (1971) Aug., p. 606

31) $H$. Fiedler, $H . J$. Spies, $H$. Müller, and $C$. Weiss: Neue Hüstte, $21(1976) 6$, p. 328

32) T. V. Philip: Met. Tech., 2(1975) 12, p. 554

33) $A$. Randak and $J$. Kurzeja: Stahl u. Eisen, 86(1966) 16, p. 1017

34) $J$. Campbell and $J$. $W$. Bannister: Met. Tech., 2(1975), p. 409

35）たとえば，湯河透，河合伸泰：日本金属学会会 報，13(1974) 2，p. 131

36) G. Wilson and P. W. Jack son: Powder Met., 16 (1973) 32, p. 257

37 ) 新井透，小松 登：鉄と鋼，61(1975)2, p. 241

38) 河合伸泰, 本間克彦, 滝川博, 平野稔, 立野 常男，森本暁明：鉄と鋼，63(1977) 11，S830

39) 安藤 寿, 阔山昭, 添野 沾: 鉄と鋼, 61 (1975) 11, p. 2629

40) R. D. Lupi: Cutting Tool Eng., 22 (1975) 7 8, p. 12

41) N.H. Cook and P. N. NaYAK: 米国政府研究 交献シリーズ No. 4837 (Jun. 15-1969)

42) $R$. Brownsword, $A$. G. Hague, $R$. F. Panton, and T. Pyle: Materials for Metal Cutting (1970 ISI), p. 38

43) $H$. Opitz and $W$. Konig: Materials for Metal Cutting (1970 ISI), p. 6

44) $P . K$. Wright and $E . M$. Trent: Met. Tech., 1 (1974) 1, p. 13

45）大草喜太雄, 高橋尚郎, 西沢将敏：精密機械，41 (1975) 5，p. 405

46) 大草喜太雄, 高橋尚郎, 西沢将敏：精密機械, 43 (1977) 7, p. 777

47) $Y u$. G. Kabalon: Machines and Tooling, 44 (1973) 4, p. 56

48) 大沢真澄, 新井透, 熊谷真一郎：不二越技報, 17 (1961) 2, p. 27

49) E. D. Doyle: Wear, 27 (1974), p. 295

50）估久間健人，辛島誠一：日本機械学会論文集，36 (1970) 700 , p. 14

51) 田中義信, 井川直哉, 安木国晴: 精密機械, 39 (1973), p. 1055

52) P. F. Thomason: JMES, 15 (1973), p. 200

53) 日井英治：切削工具の脆性損賃に関するシンポジ ウム資料 (昭52. 2. 24 精機学会), p. 14

54) $A$. Kasak and $T$. A. Neumeyer: Met. Trans., 3 (197) 8, p. 2281

55) D. Bhattacharyya, $A$. Hajra, $A$. Basu, and S. JanA: Weav, 42 (1977), p. 63

56) 清永欣吾: 切削工具の脆性損甥に関するシンポジ ウム資料（昭 52.2.24 精機学会)，p. 68

57) A. R. Johnson: Climax Mo. Co. 報告 L 30042 (1976)

58）高島始弘，源内規夫，福塚淑郎：鉄と鋼，62 (1976) 11, S 772

59) G. Berry, $M . J$. Kadhim, and $A l$-Ternachi: 
Met. Tech. 4 (1977) Jun., p. 289

60）新持喜一, 浦野元一: 塑性と加工， 12 (1971) 3, p. 229

61) G. N. Tkemaladze: Machines and Tooling (USSR), 44 (1973) 2, p. 44

62）石川英次郎，須藤興一：鉄と鋼，60（1974） 3, $\mathrm{S} 171$

63) $R$. Schlatter and $J$. Stepanics: Metal Prog., (1976) Jun., p. 56

64) A. R. Johnson: Climax Mo, Co 報告 L300-20

65) R. J. Henry: International Colloq. on HSS (Nov. 1975), p. 32

66) I. Kh. Kutuev: Metalloved Term Obrab. Met. (1976) 11, p. 26

67) L. S. Kremenev: Metalloved Term Obrab. Met. (1976) 8, p. 64

68) $J$. Chodorowski, $K$. Jurczak, and $J$. Lampe: JISI, (197I) Sep., p. 750

69) $J$. Berthon, $J$. Charrier, and $F$. Maratray: Stahl u. Eisen, 96 (1976) 5, p. 215

70) $R . A$. Zykova, $V . V$. Levitin, $L . K$. OrzhitsKAyA, and $V$. I. Babenko: Fiz. Met. Metalloved, 42 (1976) 5, p. 981

71) $O$. Mülder and $E$. Kunze: DEW. Tech. Ber. 4 (1964) Apr., p. 67

72) Yu. A. Geller: Metalloved Term. Obrob. Met. (1976) 11, p. 17

73) E. Haberling: TEW. Tech. Ber., 1 (1975) 2, p. 127

74) G. Steven and $A . E$. Nehrenberg: Trans. ASM., 57 (1964), p. 925

75) $A$. Kulmburg, $S$. Wilmes, and $F$. Korntheuer: Arch. Eisenhüttenw., 47 (1976) 5, p. 319

76) $P$. Leckie-Ewing and $W$. $A$. Jacobsen: Met. Trans., 1 (1970) 5, p. 1427
77）浅井武二, 山崖憲一郎, 辻淵清和：鉄と鋼，59 (1973) 4 , p. 250

78）仁平宣弘，日沖 学：鉄と鋼，61（1975）12, S 641

79）石神逸男, 山中久彦：日本金属学会誌，41 (1977) 7, p. 639

80) A. N. Popandopulo and M. E. Mormuleva: Izvest Vuz Cherm. Met., 13 (1970) 7, p. 126

81) A. M. Adaskin and Yu. E. Sedov: Metalloved Term. Obrab. Met. (1976) 11, p. 12

82) I. O. Khazanov and Yu. P. Egorov: Izvest Vuz Chern. Met., (1976) 11, p. 140

83) 清永欣吾：工具鋼技術研究会（第50回）（昭48. 2. 26), p. 37

84）辻 克己，荒尾 潔：铁と鋼，60（1974）3， $\mathrm{S} 170$

85) $P$. Lenk, $U$. Thieme, $G$. Vettermann, and $C$. $W$ Ycisk: Neue Hütte, 21 (1976) 7, p. 406

86) 清永欣吾, 渡辺力蔵, 武士洋一: 日立評論, 52 (1970) 7, p. 639

87) Z. Rogalski, $J$. Wyszkowski, $W$. Panasiuk, and $J$. LAMPE: 鋳鍛造, 358 (1977) 9, p. 73

88) S. Vaidyanathan: Wear, 16 (1970), p. 255

89) 河野 昌: 金属材料, 16 (1976) 12, p. 38

90) A. Ya. Gogolev and V. I. Butenko: Machines and Tooling (USSR), 44 (1971) 11, p. 41

91) A. N. Tarasav: Metalloved Term Obrab. Met., (1976) 11, p. 29

92) I. A. Moskalenko, $P . \quad N$. Ostrik, $T . N$. Kas'yanova, O. A. KRYM, and L.I. Ivanov: Metalloved Term. Obrab. Met., (1976) 11, p. 34

93) $R$. F. Harvey: US Pat. 3827923 (Aug. 6. 1974) 